\title{
Lake restoration by in-lake iron addition: a synopsis of iron impact on aquatic organisms and shallow lake ecosystems
}

\author{
Elisabeth S. Bakker • Ellen Van Donk • \\ Anne K. Immers
}

Received: 13 June 2015/Accepted: 29 October 2015/Published online: 26 November 2015

(C) The Author(s) 2015. This article is published with open access at Springerlink.com

\begin{abstract}
Internal phosphorus loading has become a major problem in many shallow freshwater lakes over the past decades due to the build-up of phosphorus stocks in the sediment. Iron is a natural capping agent which can enhance sediment $\mathrm{P}$ binding capacity, thus reducing $\mathrm{P}$ availability and shifting a lake from an algal to a macrophyte dominated state. Iron could, however, also impose toxic effects on the biota. We therefore provide a synopsis of iron toxicity studies and lake restoration measures using iron addition. Iron toxicity studies revealed that, even though iron is an essential nutrient for growth, when added in excess, it can negatively affect aquatic organisms. We found 13 studies testing the effect of iron addition as a
\end{abstract}

Handling Editor: Piet Spaak.

E. S. Bakker $(\bowtie) \cdot$ E. Van Donk · A. K. Immers

Department of Aquatic Ecology, Netherlands Institute of Ecology (NIOO-KNAW), Droevendaalsesteeg 10, 6708 PB Wageningen, The Netherlands

e-mail: 1.bakker@nioo.knaw.nl

A. K. Immers

e-mail: anne.immers@vitens.nl

E. Van Donk

Institute of Ecology and Biodiversity, Utrecht University,

Padualaan 8, 3584 CH Utrecht, The Netherlands

Present Address:

A. K. Immers

Vitens, Oude Veerweg 1, 8001 BE Zwolle,

The Netherlands restoration measure in the field (10) or using sediment from lakes and reservoirs in the laboratory (3). Twelve of the studies reported increased $\mathrm{P}$ retention after iron addition, which depended on the iron salts used and the concentrations added in two studies, whereas one study found no effect on $\mathrm{P}$ retention. Eight out of the nine field studies that reported biotic responses found reduced chlorophyll concentrations in the water column, whereas toxic effects of iron on organisms remained absent. Iron addition was most successful when external $\mathrm{P}$ loading, and concentrations of organic matter and sulphate were low as well as densities of sediment disturbing fish and crayfish. We conclude that iron addition can be a successful restoration method when these conditions are met.

Keywords Lake restoration · Iron · Internal P loading · Toxicity

\section{Introduction}

The water quality of many freshwater lakes has been declining since the second half of the twentieth century due to high input of nutrients, mainly phosphorus $(\mathrm{P})$ and nitrogen $(\mathrm{N})$, often resulting in a shift from a clear macrophyte dominated system to a turbid algal dominated system (Søndergaard et al. 2003; Smith and Schindler 2009). Various restoration measures have been proposed by both scientists and water managers to combat these changes and return these 
lakes to their 'natural' situation which occurred prior to these eutrophication events. Great efforts have been made ever since, largely by reducing external input of nutrients by either closing off nutrient rich input sources or by pre-treating the nutrient rich water before it enters the lakes (Klapwijk et al. 1982; Jeppesen et al. 1991; Van Liere and Janse 1992). Yet a full recovery has not been reached in many cases, as restoration measures are often hindered by insufficient reduction of external loading or by internal loading of nutrients that have been building up in the lake sediment during the decades of eutrophication (Cooke et al. 1993; Søndergaard et al. 2003; Smolders et al. 2006).

One way to combat internal loading is by adding chemical substances to a lake, such as aluminium, calcium or iron, which naturally bind to $\mathrm{P}$ (Cooke et al. 1993; Burley et al. 2001; Smolders et al. 2006; Kleeberg et al. 2013). Of these compounds, iron is a compound that can be naturally found in high quantities in lake sediments, but due to changes in water regimes such as damming and excess use of groundwater for agriculture, the input of iron-rich groundwater has decreased in many areas and consequently lake sediments have become iron depleted (Van der Welle et al. 2007b; Lamers et al. 2015). The addition of iron has frequently been used in the past for pretreatment of P-rich inlet water (Klapwijk et al. 1982; Bootsma et al. 1999), but it has also successfully been used in both mesocosm experiments and field applications to combat internal $\mathrm{P}$ loading by either adding the iron to the lake sediment (Quaak et al. 1993; Boers et al. 1994; Smolders et al. 2001) or to the surface water (Jaeger 1994; Burley et al. 2001; Deppe and Benndorf 2002; Hansen et al. 2003; Kleeberg et al. 2012). Although the effects of this restoration measure on the chemical composition of lakes are well documented, the effects on different parts of the food web are often not reported.

$\mathrm{By}$ adding iron to a lake to bind to the excess $\mathrm{P}$ in the system, the lake is expected to shift towards a clear water and macrophyte dominated state (Smith and Schindler 2009). When added in excess, however, iron could also negatively affect organisms as iron in high doses can be toxic. Different toxicity experiments have been carried out in the laboratory, testing the lethal doses $\left(\mathrm{LC}_{50}\right)$ or effect doses $\left(\mathrm{EC}_{50}\right)$ of iron on various animals and plants. These investigations into the impact of toxic metals have tended to rely only on single species toxicity tests, whereas ecological effects of iron addition, such as competition, plant-herbivore interactions and predator-prey relationships eventually determine the ecosystem impact. In this synopsis we will aim to combine both lines of research on iron application (i.e. toxicity tests and restoration studies) to indicate the potential effects of iron addition as a restoration measure on different levels in the food web, from individual species to a whole lake ecosystem. First we will explore the direct and indirect effects of iron on both primary and secondary producers and assess the possible effects of iron addition on the aquatic community composition. Next we will evaluate lake restoration studies using iron and determine guidelines for successful restoration, both chemically and biologically.

\section{Iron and its biotic environment}

\section{Primary producers}

The addition of iron can have several different effects on growth and reproduction of primary producers, both direct and indirect (Wheeler et al. 1985; Snowden and Wheeler 1993; Lucassen et al. 2000). The element iron can form covalent bonds with many nutrients. The formation of these bonds with essential nutrients, such as $\mathrm{P}, \mathrm{Mn}, \mathrm{K}, \mathrm{Ca}, \mathrm{Mg}$ and $\mathrm{Zn}$, can lead to nutrient limitation and consequently to nutrient deficiencies within plants (Wheeler et al. 1985). On the other hand, by forming covalent bonds with excess $\mathrm{P}$ or highly insoluble metal-sulphides with sulphur (FeS or pyrite), iron can improve water quality for plants and act as a detoxification mechanism by reducing the availability of phytotoxins to plants (Smolders et al. 2001). Iron itself is also an essential nutrient for primary producers, where it is involved in photosynthesis, chlorophyll synthesis, respiration and nitrogen assimilation (Lucaç and Aegerter 1993). The essentiality, however, is limited to a certain concentration, after which iron becomes toxic, the so called 'window of essentiality' (Walker et al. 2012). At low concentrations, iron increases primary producers' productivity, but at elevated concentrations, iron can induce oxidative stress on a cellular level and disrupt cell membranes, proteins, pigments and even damage DNA, eventually leading to death of the organism (Linton et al. 2007; Sinha et al. 2009; Keller et al. 2012). Moreover, high 
metal concentrations within plants and algae can cause metal binding to the cell wall, which could reduce growth by inhibiting nutrient uptake or by efflux pumping of metals at the plasma membrane (Spijkerman et al. 2007).

Iron toxicity can also directly influence productivity and reproduction of plants by reducing leaf size or causing leaf and shoot dieback, by forming necrotic spots on leaves, by inducing root flaccidity and by reducing root branching (Lucassen et al. 2000; Van der Welle et al. 2007b). Until now these direct effects of iron toxicity have only been observed for terrestrial or emergent wetland plant species growing on sediments with high iron concentrations of $50-68 \mathrm{mg} \mathrm{L}^{-1}$ and $109-438 \mathrm{mg} \mathrm{g}^{-1}$ in pore water or sediment, respectively (Jones and Etherington 1970; Wheeler et al. 1985; Lucassen et al. 2000; Van der Welle et al. 2007a; Siqueira-Silva et al. 2012). Some wetland species already show signs of iron toxicity at pore water iron concentrations of $1 \mathrm{mg}$ iron $(\mathrm{Fe}) \mathrm{L}^{-1}$ (Batty and Younger 2003). However, iron deficiency has also been observed in wetland plants (Van der Welle et al. 2007a). Tests revealed that adding iron (25-100 $\mathrm{g} \mathrm{Fe} \mathrm{m}^{-2}$ ) to the water column did not directly affect growth and physical appearance of the fully submerged aquatic species Elodea nuttallii (Planch.) St. John, Potamogeton pectinatus L. 1753 (Immers et al. 2014), P. acutifolius Link 1818, Stratiotes aloides L. 1753 (Van der Welle et al. 2006, 2007b), Myriophyllum aquaticum (Vell.) Verdc (Kamal 2004) and the charophyte species Chara virgata Kützing 1834 and C. globularis Thuiller 1799 (Immers et al. 2013). Experiments with macrophytes growing in industrial metal-rich areas $\left(8.6 \mathrm{mg} \mathrm{Fe} \mathrm{L}^{-1}\right.$ in surface water and $0.75 \mathrm{mg} \mathrm{Fe} \mathrm{g}^{-1}$ sediment of which 0.21 exchangeable $\mathrm{Fe}$ ) also showed that aquatic macrophytes were able to grow well without showing any external abnormalities (Nayek et al. 2010). While these macrophytes did not show any visible symptoms of iron stress, the tolerance of aquatic plants to higher iron concentrations $\left(10-100 \mathrm{mg} \mathrm{Fe} \mathrm{L}^{-1}\right.$ in surface water) has been found to be species specific and could be negatively related to growth rate (Snowden and Wheeler 1993; Nayek et al. 2010). At high availability of sulphides, iron can become limiting for chlorophyll formation, as indicated by chlorosis, which was observed to occur in Stratiotes aloides at summer concentrations of $0.11-0.25 \mathrm{mg} \mathrm{Fe} \mathrm{\textrm {L } ^ { - 1 }}$ in the water column and in the winter, when the plants are at the sediment, sediment pore water concentrations were 0.38-0.98 $\mathrm{mg} \mathrm{Fe} \mathrm{L}^{-1}$ (Smolders et al. 1996) .

Effects of iron addition on phytoplankton have been intensively investigated for oceans, where phytoplankton growth in areas with high nitrate concentrations and low chlorophyll concentrations is highly limited by iron (Martin et al. 1991). Iron addition in oceans consequently resulted in an increase of phytoplankton growth and abundance (Martin et al. 1991; Boyd et al. 2007). Freshwater systems, however, differ greatly in nutrient composition and iron availability and iron addition does therefore not necessarily yield the same response in phytoplankton growth. Microand macronutrient addition experiments by Downs et al. (2008) showed that most phytoplankton in freshwater lakes was limited by $\mathrm{P}$, although growth of certain heterocystous cyanobacterial species was promoted by iron addition $\left(1.6 \mathrm{mg} \mathrm{Fe} \mathrm{L}^{-1}\right.$ in a eutrophic lake) due to the high $\mathrm{Fe}$ demands of these species for nitrogen assimilation. In contrast, iron addition experiments with the freshwater green algae Pseudokirchneriella subcapitata (Korshikov) F.Hindák 1990 showed that additions of $10 \mathrm{mg} \mathrm{Fe}^{2+} \mathrm{L}^{-1}$ and $25 \mathrm{mg} \mathrm{Fe}^{3+} \mathrm{L}^{-1}$ yielded lower growth rates compared to control conditions without addition of iron (Keller et al. 2012). Toxin production in cyanobacteria can also be affected by iron, decreasing with higher iron concentrations (Lucaç and Aegerter 1993), but this response was not consistent for all tested cyanobacterial species (Utkilen and Gjolme 1995).

Whereas iron addition could eventually alleviate light limitation by returning the ecosystem to a macrophyte dominated state with high water transparency, iron can simultaneously precipitate as iron hydroxides on plants and lake sediments, which in turn could induce light limitation and inhibit growth of both plants and periphyton (Gerhardt and Westermann 1995). Not only at the surface of the plants, but also in the oxygenated sediment near the roots iron hydroxides are formed, which can be visible as red plaques coating the root surface. When iron concentrations in the water column or sediment are high, excess uptake of iron within plants may lead to the formation of toxic reactive oxygen species (ROS) within cells (Sinha et al. 2009). In order to avoid intracellular damage, oxygen can be excreted at the tips of the roots, which in turn reacts with dissolved iron to form iron oxyhydroxides. The plaques could serve as iron storage in case of iron shortage, serve as a protective 
barrier against uptake of (other) toxic metals, but could also inhibit the uptake of essential nutrients by the roots (Snowden and Wheeler 1995; Siqueira-Silva et al. 2012). However, the effectiveness of the formation of root plaques as a protection against hyper-accumulation of iron within cells is debated (Siqueira-Silva et al. 2012).

\section{Secondary producers}

Even though animals require iron for haemoglobin in blood cells and various enzymes (such as cytochromes which are involved in ATP production) and use iron as a detoxification mechanism against heavy metals (Vuori 1995), iron can cause serious damage to animals when concentrations reach beyond the window of essentiality. On a cellular level high iron concentrations can disrupt cell membranes, damage DNA and enhance lipid peroxidative damage through the formation of ROS (Gerhardt and Westermann 1995). Moreover, iron may also affect behaviour or life cycle strategies as high iron concentrations can cause a decrease in number of offspring (Myllynen et al. 1997), reduce the viability of offspring (Myllynen et al. 1997; Van Anholt et al. 2002), increase susceptibility to bacterial pathogens (Sealey et al. 1997) and interfere with digestion and consequently reduce the uptake of nutrients (Gerhardt 1992; Van Anholt et al. 2002). The severity of these effects is strongly coupled to the concentration of iron encountered by the animal and differs greatly among species. For instance iron-rich low $\mathrm{pH}$ mining lakes still harbour rudimental benthic communities, where benthic filamentous algae and a few species of zooplankton and macro-invertebrates can survive at water iron concentrations of $0.4-400 \mathrm{mg} \mathrm{Fe} \mathrm{L}^{-1}$ (Wollmann et al. 2000; Wollmann 2000; Kleeberg et al. 2006).

\section{Direct toxicity tests}

Many direct toxicity experiments have been carried out to test the effect dose $\left(\mathrm{EC}_{50}\right)$ and lethal dose $\left(\mathrm{LC}_{50}\right)$ of iron on both benthic and pelagic animals (Table 1). These tests often used high concentrations of iron to represent lakes or rivers which had been acidified or polluted with heavy metals due to mining or other industrial activities (Van Anholt et al. 2002; Verberk et al. 2012). The results clearly show a big difference in the response of the tested animals to iron concentrations, even among species of the same order (Table 1). The high variation could partly be explained by variability in dissolved versus particulate iron, iron speciation and water hardness among studies, whereas additionally, possible effects of iron addition on $\mathrm{pH}$ and concentrations of other toxic metals were not always carefully separated. In the case of Daphnia, for example, Biesinger and Christensen (1972) showed that relatively low additions of $\mathrm{FeCl}_{3}$ impaired survival of both adult and young. Yet followup experiments showed that Daphnia magna Straus 1820 and D. longispina O. F. Müller 1776 seemed unaffected by higher dissolved iron concentrations and that the particulate nature of the added iron sulphate and the decrease in $\mathrm{pH}$ caused the mortalities and reduced number of broods, not the toxicity of the metal itself (Randall et al. 1999; Van Anholt et al. 2002). Acute toxicity experiments with $\mathrm{FeCl}_{3}$ yielded low $\mathrm{LC}_{50}$ values for other pelagic animals, such as for the warm water fish Rasbora sumatrana Bleeker 1852 and Poecilia reticulata Peters 1859 and the amphibian species Duttaphrynus melanostictus Schneider 1799 (Shuhaimi-Othman et al. 2012a). Although iron addition showed physical damage within tissues of these animals (Shuhaimi-Othman et al. 2012a), the animals were tested in water with low water hardness, whereas low water hardness is known to increase toxicity of metals to organisms (Khangarot 1991). Moreover, according to Randall et al. (1999), acute iron toxicity rarely occurs in fish, but chronic toxicity might occur after prolonged exposure.

Various benthic and pelagic macroinvertebrates show a high tolerance for iron, such as the mollusc Melanoides tuberculata Müller 1774 which could withstand high iron concentrations by closing its tightly sealing operculum (Gerhardt 1992; ShuhaimiOthman et al. 2012a). The mayfly Leptophlebia marginata L. 1767 stopped feeding during the time of high iron concentrations up to $50 \mathrm{mg} \mathrm{Fe} \mathrm{L}^{-1}$ and showed $95 \%$ survival after 2 weeks (Gerhardt 1992). However, after prolonged exposure to high iron concentrations, the mayflies started to die due to starvation and constipation (Gerhardt 1992). A big difference was found between the different oligochaete species and their tolerance for iron. Whereas Tubifex tubifex Müller 1774 and Branchioma sowerbyi Beddard 1892 could withstand extremely high iron concentrations (Mukhopadhyay and Konar 1984; Khangarot 1991), Nais elinguis Müller 1774 was only 


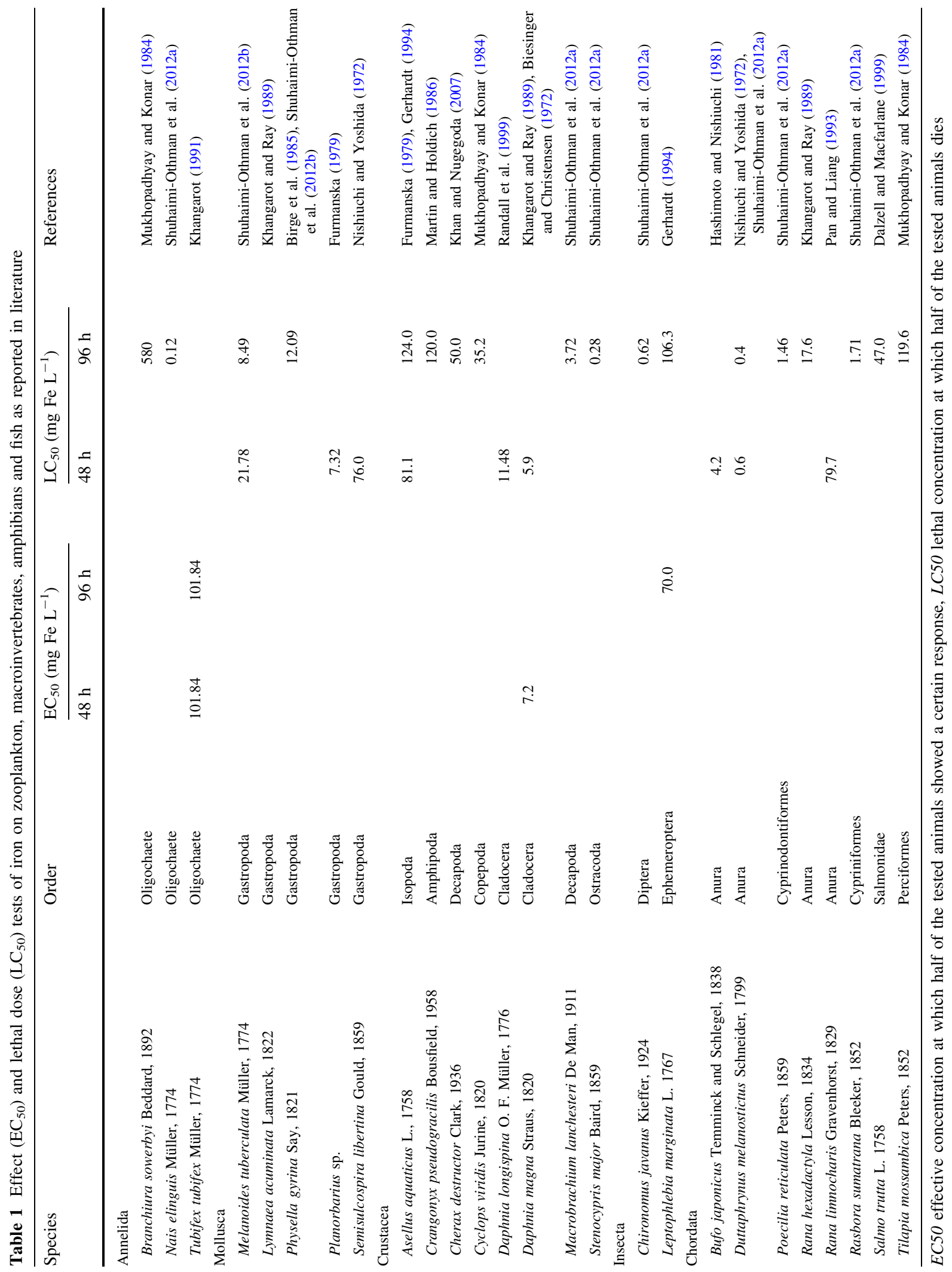


able to survive very low concentrations (ShuhaimiOthman et al. 2012a). Aquatic oligochaete species are often used as environmental indicators for water quality due to the fact that some species can withstand highly polluted areas, whereas others are only found in unpolluted areas (Chapman et al. 1982).

Iron toxicity under natural conditions

In iron toxicity studies iron and $\mathrm{pH}$ effects need to be carefully separated, but during field experiments these effects may occur together and could increase toxicity, not to mention co-precipitation of other toxic metals. Moreover, iron could precipitate as iron hydroxide, which can alter food quality, food availability, habitat structure and can attach to vital parts of animals, resulting in stress and tissue damage in benthic feeding macro-invertebrates and fish (Gerhardt and Westermann 1995; Vuori 1995; Linton et al. 2007; SiqueiraSilva et al. 2012). These indirect effects of iron precipitates on macro-invertebrates and fish, plants, lake sediment and other surfaces have shown to be eventually more detrimental to animal growth than possible toxic effects of iron within cell tissues (Gerhardt and Westermann 1995; Vuori 1995; Linton et al. 2007). Iron hydroxide precipitates, both aboveground and belowground (iron plaque layers), can decrease growth of food plants and when ingested can attach to gill and gut membranes, disturbing animal metabolism and mobility, thereby restricting foraging behaviour (Rasmussen and Lindegaard 1988; Gerhardt and Westermann 1995; Siqueira-Silva et al. 2012). Iron hydroxide layers on the sediment could alter the structure and quality of benthic habitats and destroy spawning grounds for fish (Rasmussen and Lindegaard 1988; Gerhardt and Westermann 1995; Linton et al. 2007). Direct accumulation of iron precipitates on fish and macroinvertebrate gills has led to restricted respiration in various animals (Gerhardt and Westermann 1995; Vuori 1995; Linton et al. 2007). Moreover, precipitated iron deposits on eggs showed a decrease in hatching success as the iron clogged the egg pores, resulting in suffocation of the offspring (Vuori 1995; Linton et al. 2007). Nonetheless, these negative effects of iron precipitates on zooplankton and fish were not observed during the iron addition experiment of Jaeger (1994), even though the sediment was covered with an ironhydroxide layer and surface water iron concentrations reached $4 \mathrm{mg} \mathrm{Fe} \mathrm{L}^{-1}$.
Effects of iron on community shifts

As shown in the previous paragraphs, iron can have several positive and negative effects on species, both primary and secondary producers. Therefore, iron addition in the field could induce changes on a community level due to the differences in iron tolerance between species or groups of species. The formation of iron precipitates on plants has for example been observed to restrict the distribution of various plant and periphyton species in streams (Vuori 1995). Therefore, differences in plant responses to iron addition, both direct and indirect, might lead to a shift in community composition, favouring growth of the more iron-tolerant species. Iron addition could lead to a higher abundance and diversity of endangered macrophyte species as Geurts et al. (2008) showed that the occurrence of endangered plant species such as charophytes was related to high $\mathrm{Fe}: \mathrm{P}$ ratios in the sediment pore water of peat lakes. Additionally, the germination of several charophyte species on peat sediments was not hindered by iron additions up to $40 \mathrm{~g} \mathrm{Fe} \mathrm{m}^{-2}$ (Immers et al. 2014). Therefore, the shift in community composition after iron addition would not necessarily lead to dominance of fast growing macrophyte species or algae.

Differences in iron tolerance between macroinvertebrate species has also been shown to affect community composition. High iron concentrations in a Danish lowland river led to a decrease in macroinvertebrate taxa, with only the taxa Tubificidae, Chironomidae and Tipulidae present, whereas the pollution sensitive taxa Ephemeroptera and Plecoptera were confined to areas with low iron concentrations (Rasmussen and Lindegaard 1988). Diversity of macroinvertebrates was shown to decrease at iron concentrations above $1.2 \mathrm{mg} \mathrm{Fe} \mathrm{L}{ }^{-1}$, but even at low concentrations of $0.2-0.3 \mathrm{mg} \mathrm{Fe} \mathrm{L}^{-1}$ the number of macroinvertebrate taxa decreased from 67 to 53 (Rasmussen and Lindegaard 1988; Gerhardt and Westermann 1995). Moreover, precipitations of iron on plants, periphyton and sediments have shown to eliminate macroinvertebrate grazers that feed on biofilm and periphyton (Rasmussen and Lindegaard 1988). Chapman et al. (1982) showed that oligochaetes adapted to oligotrophic conditions were more tolerant to high metal concentrations (mercury and cadmium) than species adapted to eutrophic conditions. Nonetheless, metal tolerance in macroinvertebrates changed with varying 
environmental conditions, such as shifts in $\mathrm{pH}$ and temperature (Chapman et al. 1982).

Higher iron requirements of certain species can also induce community changes such as in phytoplankton communities, where iron additions have caused a shift towards $\mathrm{N}$-fixing cyanobacterial species over green algae (Downs et al. 2008; Molot et al. 2010). In this case iron availability changed and the species with higher iron requirements, such as heterocystous cyanobacteria, could grow faster, resulting in a shift in phytoplankton dominance (Downs et al. 2008; Molot et al. 2010).

Lastly, iron additions can change communities due to behavioural avoidance, as was shown by Verberk et al. (2012) for two stickleback species. They concluded that the three-spined stickleback showed behavioural avoidance to areas with high iron concentrations, whereas the nine-spined stickleback preferred these areas. Nonetheless after iron concentrations were reduced, the three-spined stickleback returned to the formerly iron contaminated areas (Verberk et al. 2012). This non-lethal effect of high iron concentrations on community composition was also shown for other fish and benthic invertebrates (Rasmussen and Lindegaard 1988; Gerhardt and Westermann 1995; Vuori 1995; Randall et al. 1999).

While all previous mentioned consequences of high iron concentrations could result in considerable changes in the community composition of the aquatic ecosystem and may lead to reduced diversity, excess iron in the water could also bind to excess $\mathrm{P}$ in the system, thereby shifting eutrophic ecosystems to macrophyte dominated mesotrophic or oligotrophic ecosystems with higher biodiversity (Jeppesen et al. 2012). Lower P concentrations in the water favour macrophyte growth over phytoplankton growth, resulting in increased water transparency.

\section{Iron addition as a restoration measure}

\section{Chemical interactions}

The goal of adding iron to the sediment or surface water of a lake is to bind the available $\mathrm{P}$, mostly in the form of phosphate $\left(\mathrm{PO}_{4}{ }^{3-}\right)$ in the water and form a 'phosphate-trap' on the sediment-water interface. However, the binding capacity of Fe is regulated by the redox potential in the top layer of the sediment
(Lijklema 1977; Burley et al. 2001; Smolders et al. 2006). Under oxic conditions, oxidised ferric iron $\left(\mathrm{Fe}^{3+}\right)$ can freely precipitate with $\mathrm{PO}_{4}{ }^{3-}$, but under anoxic or reduced conditions, ferrous iron $\left(\mathrm{Fe}^{2+}\right)$ is formed and $\mathrm{Fe}$ partly loses its binding capacity and consequently $\mathrm{PO}_{4}{ }^{3-}$ will be released from the sediment to the water layer (Mortimer 1941; Lijklema 1977; Cooke et al. 1993; Golterman 2001). Moreover, high sulphate $\left(\mathrm{SO}_{4}{ }^{2-}\right)$ concentrations can facilitate internal eutrophication by competing with $\mathrm{PO}_{4}{ }^{3-}$ for anion adsorption sites, which ultimately results in mobilisation of previously bound $\mathrm{PO}_{4}{ }^{3-}$ to the water column (Smolders et al. 2006; Van der Welle et al. 2007a). Additionally, high $\mathrm{SO}_{4}{ }^{2-}$ reduction rates in organic sediments lead to the formation of toxic sulphides $\left(\mathrm{S}^{2-}\right)$, which reduce the formed iron-phosphates to form $\mathrm{FeS}_{\mathrm{x}}$ (Smolders et al. 2006). Therefore, $\mathrm{Fe}$ addition can only be successful in reducing internal $\mathrm{P}$ loading when $\mathrm{SO}_{4}{ }^{2-}$ concentrations are low or when sufficient $\mathrm{Fe}$ is added to cope with these $\mathrm{SO}_{4}{ }^{2-}$ interactions (Lamers et al. 2002). A positive effect of $\mathrm{FeS}_{\mathrm{x}}$ formation is that iron addition may also reduce the amount of toxic sulphides, thus benefitting plant growth (Van der Welle et al. 2006; Lamers et al. 2015).

The success of iron addition in order to regulate $\mathrm{P}$ release can be calculated by using the Fe:P ratio in the sediment pore water. Various ratios are suggested in literature, ranging from a molar pore water ratio of 1-3.5 (Smolders et al. 2001; Zak et al. 2004; Geurts et al. 2008), to a pore water ratio of 15 by weight (Jensen et al. 1992), to a molar Fe:P ratio of 8-10 for the sediment (Hansen et al. 2003; Geurts et al. 2008). These values would need to be reached or exceeded to enable $\mathrm{P}$ retention in the (oxidised) sediment.

Additionally, humic compounds can form stable humic-iron complexes with iron, which could inhibit the formation of iron-phosphates and iron-oxides (Myllynen et al. 1997; Zak et al. 2004; Spijkerman et al. 2007). Therefore, high concentrations of organic matter and other chemical elements with high affiliation to $\mathrm{Fe}$ (such as sulphate) interfere with the aim of $\mathrm{P}$ retention through iron addition. Iron addition in organic-rich lakes does not increase $\mathrm{P}$ retention until dissolved organic carbon (DOC) concentrations have sufficiently decreased (Zak et al. 2004). Part of the reactive $\mathrm{Fe}$ will bind to humic compounds, thereby lowering the effective iron dose to immobilise sediment $\mathrm{P}$. 
Lastly, due to the low $\mathrm{pH}$ of $\mathrm{FeCl}_{3}$, adding large quantities of iron may lead to a drop in $\mathrm{pH}$, which in turn leads to increased solubility of other metals in water. This may subsequently lead to problems for aquatic organisms. To prevent a quick drop in $\mathrm{pH}$ and direct effects of high iron concentrations during the iron addition period on aquatic organisms, the speed of addition should depend on the buffer capacity and hydrological circumstances of the lake, resulting in a gradual addition of iron over a longer term (months to years). Another option is to add a buffer solution during the addition of $\mathrm{Fe}$ (e.g. $\mathrm{NaOH}$ ).

Lake restoration by iron addition: case studies

We found 13 iron addition studies which have been performed in the past with the aim of lake restoration, from which we discuss the results, both chemically and biologically (Table 2). In 3 of these experiments iron compounds were added to sediment cores in the laboratory and in 10 field experiments (in lakes or reservoirs) iron compounds were added either to the sediment ( 2 occasions) or to the water column (9 occasions - one used both water and sediment addition).

Different iron salts have been added in field studies as a restoration measure, which included $\mathrm{FeCl}_{3}, \mathrm{FeCl}_{2}$, $\mathrm{FeSO}_{4}$ and $\mathrm{Fe}_{2} \mathrm{O}_{3}$, with or without extra aeration of the lake (Quaak et al. 1993; Boers et al. 1994; Jaeger 1994; Smolders et al. 2001; Hansen et al. 2003). P retention increased in most studies using the iron salts $\mathrm{FeCl}_{2}$, $\mathrm{FeCl}_{3}, \mathrm{FeSO}_{4}$, whereas it was barely affected after addition of $\mathrm{Fe}_{2} \mathrm{O}_{3}$ (Smolders et al. 2001; Table 2). Furthermore, in a direct comparison, addition of $\mathrm{FeSO}_{4}$ resulted in less $\mathrm{P}$ retention compared to the use of iron salts (Smolders et al. 2001). Both addition of iron salts to the sediment and to the water column yielded increased $\mathrm{P}$ retention (Table 2). The laboratory studies and several field studies indicate that the sediment pore water $\mathrm{Fe}: \mathrm{P}$ ratio determines the strength of $\mathrm{P}$ release and retention (Burley et al. 2001; Smolders et al. 2001; Hansen et al. 2003; Geurts 2010; Kleeberg et al. 2012; Immers et al. 2015). Therefore, at first sight, the addition of iron to the sediment seems more effective than in the water column, even though in practice it is much easier to add iron to the water column at a whole lake scale. However, when added in the water column in the field, strong precipitation of iron compounds was observed, which co-precipitates both suspended organic material as well as water column phosphorus, contributing to reduced phytoplankton biomass and improved water transparency (Jaeger 1994; Kleeberg et al. 2012; Immers et al. 2015). Furthermore, the sediment-water interface is dynamic, as there can be strong resuspension of sediments due to storms (e.g. Boers et al. 1994). Therefore, whether iron salts are applied in the water column or sediment, there will be a continuous exchange and redistribution of the added iron.

Whereas sediment resuspension can induce a flux of $P$ in the water column (Boers et al. 1994), it can simultaneously result in new precipitation of water column $\mathrm{P}$ through the temporary mixing of iron particles in the water column. In the field studies the added iron spread quite well horizontally, away from the source of application throughout the water bodies, either facilitated by injecting the iron salts into an ascending water jet (Deppe and Benndorf 2002) or through wind induced water circulation (Immers et al. 2015). For the vertical distribution of iron, stratification plays a crucial role in the effect of iron additions. When added in the water column in the epilimnion, the iron does not reach the sediment and hence does not reduce release of $\mathrm{P}$ from the sediment. Still during thermal stratification, this can result in reduced $\mathrm{P}$ availability in the water column, reduced algal growth and improved water transparency (Walker et al. 1989). However, upon erosion of the thermocline in the course of the season, and complete mixing of the lake or reservoir, the accumulated $\mathrm{P}$ in the hypolimnion is released and can cause new algal blooms (Walker et al. 1989). Several lake restoration projects therefore combine iron addition with breaking of the lake stratification through the use of pumps, both to ensure spread of the added iron throughout the water body and to reach the sediment, as well as to increase oxygen availability at the sediment-water interface (Walker et al. 1989; Dahldorph and Price 1994; Jaeger 1994; Deppe and Benndorf 2002; Kleeberg et al. 2012).

Whereas enough oxygen availability is considered a prerequisite for successful binding of $\mathrm{P}$, the studies that compared the effect of iron addition on $P$ retention with and without aeration or oxygen supply, did not find evidence that more $\mathrm{P}$ was bound at enhanced oxygen concentrations (Burley et al. 2001; Hansen et al. 2003; Kleeberg et al. 2012). This may suggest that there was still insufficient iron available despite the addition (Hansen et al. 2003), P release was 
Table 2 An overview of performed restoration experiments using iron addition and their effect on P retention and aquatic biota

\begin{tabular}{|c|c|c|c|c|c|c|c|c|c|}
\hline \multicolumn{2}{|l|}{$\begin{array}{l}\text { Restoration } \\
\text { experiments }\end{array}$} & \multicolumn{2}{|c|}{$\begin{array}{l}\text { Field/ } \\
\text { laboratory }\end{array}$} & \multicolumn{2}{|c|}{$\begin{array}{l}\text { Location/origin } \\
\text { sediment }\end{array}$} & $\begin{array}{l}\text { Mean } \\
\text { water } \\
\text { depth }\end{array}$ & Addition & Amount & $\begin{array}{l}\text { Location } \\
\text { of } \\
\text { addition }\end{array}$ \\
\hline \multicolumn{2}{|l|}{$\begin{array}{l}\text { Burley et al. } \\
\text { (2001) }\end{array}$} & \multicolumn{2}{|c|}{$\begin{array}{l}\text { Laboratory, } \\
\text { sediment } \\
\text { cores }\end{array}$} & \multicolumn{2}{|c|}{$\begin{array}{l}\text { Crooked Lake, Amisk } \\
\text { Lake and Baptiste Lake, } \\
\text { Canada }\end{array}$} & - & $\mathrm{FeCl}_{3}, \mathrm{FeCl}_{3} \pm \mathrm{O}_{2}$ & $100 \mathrm{~g} \mathrm{Fe} \mathrm{m}^{-2}$ & $\begin{array}{l}\text { Water } \\
\text { column }\end{array}$ \\
\hline \multicolumn{2}{|l|}{$\begin{array}{l}\text { Hansen et al. } \\
(2003)\end{array}$} & \multicolumn{2}{|c|}{$\begin{array}{l}\text { Laboratory, } \\
\text { sediment } \\
\text { cores }\end{array}$} & \multicolumn{2}{|c|}{ Lake Vedsted, Denmark } & - & $\mathrm{FeCl}_{3}$ ( \pm aeration $)$ & $\begin{array}{l}0.2 \mathrm{~g} \mathrm{Fe} \mathrm{core}^{-1} \\
\quad\left(=0.65 \mathrm{~g} \mathrm{Fe} \mathrm{L}^{-1}\right. \\
\text { sediment })\end{array}$ & Sediment \\
\hline \multirow{2}{*}{\multicolumn{2}{|c|}{$\begin{array}{l}\text { Smolders et al. } \\
\text { (2001) }\end{array}$}} & \multirow{2}{*}{\multicolumn{2}{|c|}{$\begin{array}{l}\text { Laboratory, } \\
\text { sediment } \\
\text { cores }\end{array}$}} & \multirow{2}{*}{\multicolumn{2}{|c|}{$\begin{array}{l}\text { De Bruuk, The } \\
\text { Netherlands }\end{array}$}} & - & $\mathrm{FeCl}_{3}, \mathrm{FeCl}_{2}, \mathrm{FeSO}_{4}$ & $\begin{array}{l}150,500 \text { and } \\
1500 \mathrm{mg} \mathrm{Fe} \mathrm{kg}^{-1}\end{array}$ & Sediment \\
\hline & & & & & & - & $\mathrm{Fe}_{2} \mathrm{O}_{3}$ & $\begin{array}{l}150,500 \text { and } \\
1500 \mathrm{mg} \mathrm{Fe} \mathrm{kg}^{-1}\end{array}$ & Sediment \\
\hline \multicolumn{2}{|l|}{$\begin{array}{l}\text { Daldorph and } \\
\text { Price (1994) }\end{array}$} & \multicolumn{2}{|l|}{ Field } & \multicolumn{2}{|c|}{$\begin{array}{l}\text { Foxcote Reservoir, } \\
\text { England }\end{array}$} & n.a. & $\mathrm{FeSO}_{4}+$ aeration & $3.5 \mathrm{mg} \mathrm{Fe} \mathrm{L}^{-1}$ & $\begin{array}{l}\text { Water } \\
\text { column }\end{array}$ \\
\hline \multicolumn{2}{|c|}{$\begin{array}{l}\text { Deppe and } \\
\text { Benndorf (2002) }\end{array}$} & \multicolumn{2}{|l|}{ Field } & \multicolumn{2}{|c|}{$\begin{array}{l}\text { Bautzen reservoir, } \\
\text { Germany }\end{array}$} & $7.4 \mathrm{~m}$ & $\begin{array}{l}\mathrm{FeCl}_{3}, \mathrm{FeCl}_{2} \\
\mathrm{FeClSO}_{4}\end{array}$ & $40 \mathrm{~g} \mathrm{Fe} \mathrm{m}^{-2}$ & $\begin{array}{l}\text { Water } \\
\text { column }\end{array}$ \\
\hline \multirow{2}{*}{\multicolumn{2}{|c|}{ Geurts (2010) }} & \multirow{2}{*}{\multicolumn{2}{|c|}{$\begin{array}{l}\text { Field, } \\
\text { mesocosms }\end{array}$}} & \multirow{2}{*}{\multicolumn{2}{|c|}{$\begin{array}{l}\text { Lake Uddelmeer, } \\
\text { The Netherlands }\end{array}$}} & $1 \mathrm{~m}$ & $\mathrm{FeCl}_{2}$ & $\begin{array}{l}50 \text { and } \\
100 \mathrm{~g} \mathrm{Fe} \mathrm{m}^{-2}\end{array}$ & Sediment \\
\hline & & & & & & $1 \mathrm{~m}$ & $\mathrm{FeCl}_{3}$ & 5 and $10 \mathrm{~g} \mathrm{Fe} \mathrm{m}^{-2}$ & $\begin{array}{l}\text { Water } \\
\text { column }\end{array}$ \\
\hline \multicolumn{2}{|l|}{$\begin{array}{l}\text { Immers et al. } \\
(2015)\end{array}$} & \multicolumn{2}{|l|}{ Field } & \multicolumn{2}{|c|}{$\begin{array}{l}\text { Terra Nova, The } \\
\text { Netherlands }\end{array}$} & $1.4 \mathrm{~m}$ & $\mathrm{FeCl}_{3}$ & $33 \mathrm{~g} \mathrm{Fe} \mathrm{m}^{-2}$ & $\begin{array}{l}\text { Water } \\
\text { column }\end{array}$ \\
\hline \multicolumn{2}{|l|}{ Jaeger (1994) } & \multicolumn{2}{|l|}{ Field } & \multicolumn{2}{|c|}{$\begin{array}{l}\text { Lake Krupunder, } \\
\text { Germany }\end{array}$} & $4.2 \mathrm{~m}$ & $\begin{array}{l}\mathrm{FeClSO}_{4}+\text { aeration } \\
\text { ('Ferri Floc') }\end{array}$ & $5 \mathrm{~g} \mathrm{Fe} \mathrm{m}^{-3}$ & $\begin{array}{l}\text { Water } \\
\text { column }\end{array}$ \\
\hline \multicolumn{2}{|l|}{$\begin{array}{l}\text { Kleeberg et al. } \\
(2012,2013)\end{array}$} & \multicolumn{2}{|l|}{ Field } & \multicolumn{2}{|c|}{$\begin{array}{l}\text { Lake Groß-Glienicke, } \\
\text { Germany }\end{array}$} & $6.8 \mathrm{~m}$ & $\begin{array}{l}\mathrm{Fe}(\mathrm{OH})_{3} \\
\quad \mathrm{FeCl}_{2} \pm \text { aeration }\end{array}$ & $250 \mathrm{~g} \mathrm{Fe} \mathrm{m}^{-2}$ & $\begin{array}{l}\text { Water } \\
\text { column }\end{array}$ \\
\hline \multicolumn{2}{|c|}{$\begin{array}{l}\text { Quaak et al. } \\
\text { (1993), Boers } \\
\text { et al. (1994) }\end{array}$} & \multicolumn{2}{|l|}{ Field } & \multicolumn{2}{|c|}{$\begin{array}{l}\text { Groot Vogelenzang, } \\
\text { The Netherlands }\end{array}$} & $1.75 \mathrm{~m}$ & $\mathrm{FeCl}_{3}$ & $100 \mathrm{~g} \mathrm{Fe} \mathrm{m}^{-2}$ & Sediment \\
\hline \multicolumn{2}{|c|}{$\begin{array}{l}\text { Van der Wal et al. } \\
\text { (2013) }\end{array}$} & $\begin{array}{l}\text { Field, } \\
\text { mesoco }\end{array}$ & & $\begin{array}{r}\text { Terra N } \\
\text { Nether }\end{array}$ & $\begin{array}{l}\text { va, The } \\
\text { lands }\end{array}$ & $0.8 \mathrm{~m}$ & $\mathrm{FeCl}_{3}$ & $85 \mathrm{~g} \mathrm{Fe} \mathrm{m}^{-2}$ & $\begin{array}{l}\text { Water } \\
\text { column }\end{array}$ \\
\hline $\begin{array}{l}\text { Van Donk et a } \\
\text { (1994) }\end{array}$ & & $\begin{array}{l}\text { Field, } \\
\text { mesoco }\end{array}$ & & $\begin{array}{r}\text { Lake } \mathrm{Br} \\
\text { The } \mathrm{N}\end{array}$ & $\begin{array}{l}\text { eukeleveen, } \\
\text { therlands }\end{array}$ & $1.45 \mathrm{~m}$ & $\mathrm{FeCl}_{3}$ & $\begin{array}{l}29 \mathrm{mg} \mathrm{Fe} \mathrm{L}{ }^{-1} \\
\quad\left(=42 \mathrm{~g} \mathrm{Fe} \mathrm{m}^{-2}\right)\end{array}$ & $\begin{array}{l}\text { Water } \\
\text { column }\end{array}$ \\
\hline $\begin{array}{l}\text { Walker et al. } \\
\text { (1989) }\end{array}$ & & Field & & Vadnais & Lake, USA & $8.1 \mathrm{~m}$ & $\mathrm{FeCl}_{3}+$ aeration & 100 kg Fe day ${ }^{-1}$ & $\begin{array}{l}\text { Water } \\
\text { column }\end{array}$ \\
\hline $\begin{array}{l}\text { Restoration } \\
\text { experiments }\end{array}$ & $\begin{array}{l}\text { Durc } \\
\text { iron }\end{array}$ & $\begin{array}{l}\text { ation of } \\
\text { addition }\end{array}$ & $\begin{array}{l}\text { Dur } \\
\text { the }\end{array}$ & $\begin{array}{l}\text { ation of } \\
\text { study }\end{array}$ & $\begin{array}{l}\text { Trophic status an } \\
\text { loading before ap }\end{array}$ & $\begin{array}{l}\mathrm{d} \mathrm{P} \\
\text { plication }\end{array}$ & Effect on $\mathrm{P}$ retention & $\begin{array}{l}\text { Reported effects on } \\
\text { and/or the lake ecos }\end{array}$ & $\begin{array}{l}\text { organisms } \\
\text { ystem }\end{array}$ \\
\hline $\begin{array}{l}\text { Burley et al. } \\
\text { (2001) }\end{array}$ & $\begin{array}{l}\text { At o } \\
(\mathrm{si} \\
\text { do }\end{array}$ & $\begin{array}{l}\text { nce } \\
\text { ngle } \\
\text { se) }\end{array}$ & 21 & lays & - & & Positive & Not available & \\
\hline $\begin{array}{l}\text { Hansen et al. } \\
(2003)\end{array}$ & $\begin{array}{r}\text { At o } \\
\text { (si } \\
\text { do }\end{array}$ & $\begin{array}{l}\text { nce } \\
\text { ngle } \\
\text { se) }\end{array}$ & 34 & lays & - & & Positive & Not available & \\
\hline $\begin{array}{l}\text { Smolders } \\
\text { et al. } \\
(2001)\end{array}$ & $\begin{array}{l}\text { At o } \\
\text { (si } \\
\text { do }\end{array}$ & $\begin{array}{l}\text { nce } \\
\text { ngle } \\
\text { se) }\end{array}$ & 89 & lays & - & & $\begin{array}{l}\text { Positive, stronger at } \\
\text { higher concentrations }\end{array}$ & Not available & \\
\hline & $\begin{array}{l}\text { At o } \\
\text { (si } \\
\text { do }\end{array}$ & & 89 & lays & - & & No & Not available & \\
\hline
\end{tabular}


Table 2 continued

\begin{tabular}{|c|c|c|c|c|c|}
\hline $\begin{array}{l}\text { Restoration } \\
\text { experiments }\end{array}$ & $\begin{array}{l}\text { Duration } \\
\text { of iron } \\
\text { addition }\end{array}$ & $\begin{array}{l}\text { Duration of } \\
\text { the study }\end{array}$ & $\begin{array}{l}\text { Trophic status and } \mathrm{P} \\
\text { loading before application }\end{array}$ & $\begin{array}{l}\text { Effect on P } \\
\text { retention }\end{array}$ & $\begin{array}{l}\text { Reported effects on organisms and/or the } \\
\text { lake ecosystem }\end{array}$ \\
\hline $\begin{array}{l}\text { Daldorph } \\
\text { and Price } \\
\text { (1994) }\end{array}$ & 11 years & 16 years & $\begin{array}{l}\text { P loading: } 12 \mathrm{~g} \\
\mathrm{P} \mathrm{m}^{-2} \text { year }^{-1}\end{array}$ & Positive & $\begin{array}{l}\text { Chlorophyll and particularly } \\
\text { cyanobacteria decreased; reservoir } \\
\text { shifted from phytoplankton dominated } \\
\text { to macrophyte dominated system three } \\
\text { years after start dosing }\end{array}$ \\
\hline $\begin{array}{l}\text { Deppe and } \\
\text { Benndorf } \\
(2002)\end{array}$ & $\begin{array}{l}\text { Spread } \\
\text { over two } \\
\text { times } \\
104 \text { days }\end{array}$ & 3 years & $\begin{array}{l}\text { TP: } 0.05-0.25 \mathrm{mg} \mathrm{P} \mathrm{L}^{-1} \\
\text { P loading: } \\
\text { 3.5-4.8 } \mathrm{g} \mathrm{P} \mathrm{m}^{-2} \text { year }^{-1}\end{array}$ & Positive & Not available \\
\hline \multirow[t]{2}{*}{$\begin{array}{l}\text { Geurts } \\
(2010)\end{array}$} & $\begin{array}{l}\text { At once } \\
\text { (single } \\
\text { dose })\end{array}$ & 13 months & TP: $0.19 \mathrm{mg} \mathrm{P} \mathrm{L}^{-1}$ & $\begin{array}{l}\text { Positive (only } \\
\text { at highest } \\
\text { concentration) }\end{array}$ & $\begin{array}{l}\text { Chlorophyll decreased; macrophytes } \\
\text { remained absent due to the anaerobic } \\
\text { sediment which counteracted } \\
\text { germination }\end{array}$ \\
\hline & $\begin{array}{l}\text { At once } \\
\text { (single } \\
\text { dose })\end{array}$ & 13 months & TP: $0.19 \mathrm{mg} \mathrm{P} \mathrm{L}^{-1}$ & No & \\
\hline $\begin{array}{l}\text { Immers } \\
\text { et al. } \\
(2015)\end{array}$ & 1.5 years & 9 years & $\begin{array}{l}\text { TP: } \\
\text { 0.020-0.130 } \mathrm{mg} \mathrm{P} \mathrm{L}^{-1} \\
\text { P loading: } \\
0.2 \mathrm{~g} \mathrm{P} \mathrm{m}^{-2} \text { year }^{-1}\end{array}$ & Positive & $\begin{array}{l}\text { Decrease in chlorophyll, suspended } \\
\text { matter and cyanobacterial biovolume, } \\
\text { submerged macrophytes reappeared; } \\
\text { no visual effects on fish }\end{array}$ \\
\hline $\begin{array}{l}\text { Jaeger } \\
\quad(1994)\end{array}$ & 6 days & 3 years & $\begin{array}{l}\text { TP: } \\
0.085-0.12 \mathrm{mg} \mathrm{P} \mathrm{L}^{-1}\end{array}$ & Positive & $\begin{array}{l}\text { Chlorophyll decreased significantly; } \\
\text { neither fish kills nor adverse effects by } \\
\text { iron hydroxide flakes on the } \\
\text { zooplankton were observed during or } \\
\text { after iron precipitation }\end{array}$ \\
\hline $\begin{array}{l}\text { Kleeberg } \\
\text { et al. } \\
\text { (2012, } \\
2013)\end{array}$ & $\begin{array}{l}\text { At once } \\
\text { (single } \\
\text { dose) }\end{array}$ & $\begin{array}{l}2 \text { years } \\
( \pm 15 \text { years } \\
\text { after Fe } \\
\text { dosing })\end{array}$ & $\mathrm{TP}: 0.48 \mathrm{mg} \mathrm{P} \mathrm{L}{ }^{-1}$ & Positive & Chlorophyll decreased significantly \\
\hline $\begin{array}{l}\text { Quaak et al. } \\
\text { (1993), } \\
\text { Boers } \\
\text { et al. } \\
\text { (1994) }\end{array}$ & 21 days & 2 years & $\begin{array}{l}\text { TP: } 0.21 \mathrm{mg} \mathrm{L}^{-1} \\
\text { P loading: } \\
\quad 3.7 \mathrm{~g} \mathrm{P} \mathrm{m}^{-2} \text { year }^{-1}\end{array}$ & Positive & $\begin{array}{l}\text { Chlorophyll decreased significantly; } \\
\text { durability of positive effects was only } \\
3 \text { months due to short water residence } \\
\text { time of lake ( } 35 \text { days) and high } \\
\text { external loading }\end{array}$ \\
\hline $\begin{array}{l}\text { Van der } \\
\text { Wal et al. } \\
(2013)\end{array}$ & 102 days & $\begin{array}{l}6 \text { weeks } \\
\text { ( } \pm 2 \text { years } \\
\text { after Fe } \\
\text { dosing) }\end{array}$ & $\begin{array}{l}\text { TP: } \\
0.037-0.047 \mathrm{mg} \mathrm{P} \mathrm{L}^{-1}\end{array}$ & Positive & $\begin{array}{l}\text { Decrease in chlorophyll and suspended } \\
\text { matter. Macrophytes remained absent } \\
\text { due to high abundance of exotic } \\
\text { crayfish }\end{array}$ \\
\hline $\begin{array}{l}\text { Van Donk } \\
\text { et al. } \\
(1994)\end{array}$ & $\begin{array}{l}\text { At once } \\
\text { (single } \\
\text { dose })\end{array}$ & 5 months & $\begin{array}{l}\text { TP: } 0.1 \mathrm{mg} \mathrm{P} \mathrm{L} \mathrm{L}^{-1} \\
\text { P loading: } \\
\quad 0.5 \mathrm{~g} \mathrm{P} \mathrm{m}^{-2} \text { year }^{-1}\end{array}$ & No & $\begin{array}{l}\text { Iron addition did not have any effect on } \\
\text { chlorophyll or suspended matter }\end{array}$ \\
\hline $\begin{array}{l}\text { Walker } \\
\text { et al. } \\
\text { (1989) }\end{array}$ & 5 years & 35 days & $\mathrm{TP}: 0.1-0.2 \mathrm{mg} \mathrm{P} \mathrm{L}^{-1}$ & Positive & $\begin{array}{l}\text { Decrease in algal productivity; durability } \\
\text { of positive effects was cut short due to } \\
\text { erosion of the thermocline in late } \\
\text { summer releasing } \mathrm{P} \text { from the } \\
\text { hypolimnion }\end{array}$ \\
\hline
\end{tabular}

$T P$ total phosphate concentration in the lake water column. Not all field studies reported both TP and P loading 
controlled by other processes (Burley et al. 2001) or the amount of $\mathrm{P}$ that could be controlled by oxygen availability was low compared to the total P loading (Kleeberg et al. 2012). According to Kleeberg et al. (2013), the success of iron addition was not hindered by the redox sensitivity of iron when added in a dimictic lake, as $\mathrm{P}$ was efficiently precipitated independent of the nature of the oxygen supply. That is, when iron was added to reach a sediment molar Fe:P ratio of 7 or more (Kleeberg et al. 2013). This condition will assure continuous $\mathrm{P}$ elimination independent of oxygen supply, as both will be released from the sediment in a ratio close to 1 and will coprecipitate due to natural oxygenation processes (Kleeberg et al. 2013). These results are in line with a thorough analysis of the processes and field experiments on the effect of aeration on $\mathrm{P}$ release and retention by Hupfer and Lewandowski (2008), who conclude that the oxygen availability at the sediment surface can control the dynamics of the short-term $\mathrm{P}$ release, but not the long-term $P$ retention.

Nine field studies measured the effect of iron addition on aquatic biota. Eight of these reported reductions in phytoplankton abundance, often expressed as chlorophyll concentrations, concomitant with reduced $\mathrm{P}$ availability in the water column (Table 2). One study found no effect on $\mathrm{P}$ availability nor phytoplankton abundance, as these were demonstrated to be regulated by the high densities of benthivorous fish in this lake (Van Donk et al. 1994). Iron addition induced shifts in the phytoplankton community composition in several studies, in particular reducing the abundance and proportion of cyanobacteria (Walker et al. 1989; Dahldorph and Price 1994; Immers et al. 2015). As a consequence of increased water transparency after iron addition, submerged macrophytes returned in several of the field studies (Dahldorph and Price 1994; Immers et al. 2015), but not in others (Geurts 2010; Van der Wal et al. 2013). In the latter, the presence of high densities of benthivorous and sediment disturbing fish and crayfish inhibited submerged macrophyte reappearance (Van Donk et al. 1994; Van der Wal et al. 2013) or sediments were deemed unsuitable for macrophyte growth due to anoxia (Geurts 2010).

Whereas high iron concentrations can have toxic effects on both primary and secondary producers in small scale laboratory experiments, these effects remained absent during the restoration projects that also monitored biological effects (Table 2). No fish kills or visual damages of gills were observed during or after iron addition and no adverse effects of iron hydroxide particles were observed on zooplankton (Jaeger 1994; Immers et al. 2015). One explanation for this could be that the high iron concentrations used in the iron toxicity studies in Table 1 are rarely reached during restoration experiments with iron addition, as dilution and chemical interactions quickly reduce the concentration of dissolved iron in the system. For example, addition of 33 and $250 \mathrm{~g} \mathrm{Fe} \mathrm{m}^{-2}$ to the water column in studies by Immers et al. (2015) and Kleeberg et al. (2012), resulted in dissolved iron concentrations in the water column of only 0.3 and $0.2 \mathrm{mg} \mathrm{L}^{-1}$, respectively.

Lake restoration by iron addition: environmental constraints

Although iron addition in the restoration studies resulted in decreased $\mathrm{P}$ availability and chlorophyll concentrations in most cases, the longevity of the success of iron addition was in some cases cut short due to a variety of factors influencing $\mathrm{P}$ concentrations, phytoplankton abundance and macrophyte success. The short-term success was in these cases due to either high or ongoing external P loading (Boers et al. 1994; Immers et al. 2015), short water retention time (Boers et al. 1994), resuspension of sediment during heavy winds or seasonal disappearance of the thermocline and mixing of the lake (Walker et al. 1989; Quaak et al. 1993), a high population of planktivorous and benthivorous fish (Van Donk et al. 1994) or invasive crayfish inhibiting the development of submerged macrophytes (Bakker et al. 2013; Van der Wal et al. 2013; Table 2). Therefore, the success of iron addition as a restoration measure is affected by location specific confounding factors, which may obscure the effects of iron addition itself.

The longevity of the success of iron addition also appears to depend greatly on the type of lake. Addition in soft-water lakes, reservoirs and dimictic lakes yielded positive results for up to eight years (Dahldorph and Price 1994; Jaeger 1994; Kleeberg et al. 2012; Table 2), whereas iron addition in alkaline lakes proved to be only a temporary solution with increasing water total phosphorous concentrations the year after iron addition, due to high $\mathrm{Fe}$ depletion rates by phosphate and sulphate and possible interactions with humic compounds (Geurts 2010, Immers et al. 2015; Table 2). For instance, in lake Groß-Glienicke 
(Germany) a high dose of at least $200 \mathrm{~g} \mathrm{Fe} \mathrm{m}^{-2}$ was calculated to be needed to bind all potentially mobile $\mathrm{P}$ and compensate for this co-precipitation of iron with organic matter (Kleeberg et al. 2012). Therefore, addition of iron in these lakes might need to be repeated to ensure positive effects on water quality in the long term. On the other hand, iron addition might not be the most suitable measure for restoration of lakes with high Fe depletion rates, which are generally lower in lakes with sand or clay sediments. For that reason, the choice of a certain chemical substance as capping agent depends on specific site conditions, and the use of other chemical substances, such as aluminium or lime, could in that case also be considered (Cooke et al. 1993; Burley et al. 2001).

Based on the success and constraints identified in the field studies, we can distil the following recommendations on the use of iron addition as a lake restoration measure. A system analysis should first reveal that internal $\mathrm{P}$ loading is the largest source of eutrophication, whereas external loading is already sufficiently reduced. Furthermore, the water body should not be subject to short retention times. The water layer should be mixed to allow the added iron to settle on the sediment. The chance of success is more likely in water bodies with a sand or clay sediment compared to organic sediments. Sediments high in sulphate are unlikely to produce good results, at least these will require higher iron dosing and more frequent application. When high densities of planktivorous and benthivorous fish or crayfish are present, these should first be reduced. Iron chlorides seem more effective in $\mathrm{P}$ retention than $\mathrm{Fe}_{2} \mathrm{O}_{3}$ or $\mathrm{FeSO}_{4}$. The appropriate dosing can be calculated based on a complete nutrient balance of the shallow water body and depends partly on the desired longevity of the measure. Particularly in situations where the natural iron supply has strongly decreased, for instance through altered hydrology and reduced seepage, the addition or iron should be considered as a measure that needs to be repeated over time.

\section{Conclusions}

Differences in species response to iron addition might lead to shifts in aquatic communities, favouring the more iron-tolerant species. Nevertheless, various experiments and lake restoration measures have shown that iron addition is effective in lowering surface water $\mathrm{P}$ concentrations, shifting the lake towards a clear macrophyte dominated system without hampering the germination and development of various endangered macrophyte species and no observations of toxic effects of iron. The longevity of these positive effects depends strongly on environmental conditions. Factors as external $\mathrm{P}$ loading, sediment type (organic or not) and in particular sulphate concentrations, lake stratification and biotic influences of sediment disturbing fish and crayfish are important in regulating $\mathrm{P}$ release and retention and may thus limit the longevity of improved water quality after iron addition.

We conclude that iron addition can be a successful restoration measure to improve water quality when the confounding environmental constraints can be effectively dealt with.

Acknowledgments This study was funded by the Water Framework Directive Innovation Fund from Agentschap NL from the Dutch Ministry of Economic Affairs, Agriculture and Innovation. This is manuscript 5959 from the NIOO-KNAW Netherlands Institute of Ecology.

Open Access This article is distributed under the terms of the Creative Commons Attribution 4.0 International License (http:// creativecommons.org/licenses/by/4.0/), which permits unrestricted use, distribution, and reproduction in any medium, provided you give appropriate credit to the original author(s) and the source, provide a link to the Creative Commons license, and indicate if changes were made.

\section{References}

Bakker ES, Sarneel JM, Gulati RD, Liu Z, Van Donk E (2013) Restoring macrophyte diversity in shallow temperate lakes: biotic versus abiotic constraints. Hydrobiologia 710:23-37

Batty LC, Younger PL (2003) Effects of external iron concentration upon seedling growth and uptake of Fe and phosphate by the common reed, Phragmites australis (Cav.) Trin ex Steudel. Ann Bot Lond 92:801-806

Biesinger K, Christensen GM (1972) Effects of various metals on survival, growth, reproduction, and metabolism of Daphnia magna. J Fish Res Board Can 29:1691-1700

Birge WJ, Black JA, Westerman AG, Short TM, Taylor SB, Bruser DM, Wallingford ED (1985) Recommendations on numerical values for regulating 26 iron and chloride concentrations for the purpose of protecting warmwater species of aquatic life in the commonwealth of Kentucky. University of Kentucky, Lexington

Boers P, Van der Does J, Quaak M, Van der Vlucht J (1994) Phosphorus fixation with iron(III)chloride: a new method 
to combat phosphorus loading in shallow lakes? Arch Hydrobiol 129:339-351

Bootsma MC, Barendregt A, Van Alphen JCA (1999) Effectiveness of reducing external nutrient load entering a eutrophicated shallow lake ecosystem in the Naardermeer nature reserve, The Netherlands. Biol Conserv 90:193-201

Boyd PW, Jickells T, Law CS, Blain S, Boyle EA, Buesseler KO et al (2007) Mesoscale iron enrichment experiments 1993-2005: synthesis and future directions. Science 315:612-617

Burley KL, Prepas EE, Chambers PA (2001) Phosphorus release from sediments in hardwater eutrophic lakes: the effects of redox-sensitive and -insensitive chemical treatments. Freshw Biol 46:1061-1074

Chapman PM, Farrell MA, Brinkhurst RO (1982) Relative tolerances of selected aquatic oligochaetes to individual pollutants and environmental factors. Aquat Toxicol 2:47-61

Cooke GD, Welch EB, Martin AB, Fulmer DG, Hyde JB, Schrieve GD (1993) Effectiveness of Al, Ca, and Fe salts for control of internal phosphorus loading in shallow and deep lakes. Hydrobiologia 253:323-335

Dahldorph P, Price R (1994) Long-term phosphorus control at 3 eutrophic reservoirs in south-eastern England. Ergeb Limnol 40:231-243

Dalzell DJB, Macfarlane NAA (1999) The toxicity of iron to brown trout and effects on the gills: a comparison of two grades of iron sulphate. J Fish Biol 55:301-315

Deppe T, Benndorf J (2002) Phosphorus reduction in a shallow hypereutrophic reservoir by in-lake dosage of ferrous iron. Water Res 36:4525-4534

Downs TM, Schallenberg M, Burns CW (2008) Responses of lake phytoplankton to micronutrient enrichment: a study in two New Zealand lakes and an analysis of published data. Aquat Sci 70:347-360

Furmanska M (1979) Studies of the effect of copper, zinc, and iron on the biotic components of aquatic ecosystems. Pol Arch Hydrobiol 26:213-220

Gerhardt A (1992) Effects of subacute doses of iron (Fe) on Leptophlebia marginata (Insecta: Ephemeroptera). Freshw Biol 27:79-84

Gerhardt A (1994) Short term toxicity of iron (Fe) and lead (Pb) to the mayfly Leptophlebia marginata (L.) (Insecta) in relation to freshwater acidification. Hydrobiologia 284:157-168

Gerhardt A, Westermann F (1995) Effects of precipitations of iron hydroxides on Leptophlebia marginata (L.) (Instecta: Ephemeroptera) in the field. Arch Hydrobiol 133:81-93

Geurts JJM (2010) Restoration of fens and peat lakes: a biogeochemical approach. Dissertation, Radboud Universiteit, Nijmegen

Geurts JJM, Smolders AJP, Verhoeven JTA, Roelofs JGM, Lamers LPM (2008) Sediment Fe: $\mathrm{PO}_{4}$ ratio as a diagnostic and prognostic tool for the restoration of macrophyte biodiversity in fen waters. Freshw Biol 53:2101-2116

Golterman HL (2001) Phosphate release from anoxic sediments or 'What did Mortimer really write? Hydrobiologia 450:99-106

Hansen J, Reitzel K, Jensen HS, Andersen FØ (2003) Effects of aluminum, iron, oxygen and nitrate additions on phosphorus release from the sediment of a Danish softwater lake. Hydrobiologia 492:139-149
Hashimoto Y, Nishiuchi Y (1981) Establishment of bioessay methods for the evaluation of acute toxicity of pesticides to aquatic organisms. J Pestic Sci 6:257-264

Hupfer M, Lewandowski JJ (2008) Oxygen controls the phosphorus release from lake sediments-a long-lasting paradigm in limnology. Int Rev Hydrobiol 93:415-432

Immers AK, Van der Sande MT, Van der Zande RM, Geurts JJM, Van Donk E, Bakker ES (2013) Iron addition as a shallow lake restoration measure: impacts on charophyte growth. Hydrobiologia 710:241-251

Immers AK, Vendrig K, Ibelings BW, Van Donk E, Ter Heerdt GNJ, Geurts JJM, Bakker ES (2014) Iron addition as a measure to restore water quality: implications for macrophyte growth. Aquat Bot 116:44-52

Immers AK, Bakker ES, Van Donk E, Ter Heerdt GNJ, Geurts JJM, Declerck SAJ (2015) Fighting internal phosphorus loading: an evaluation of the large scale application of gradual Fe-addition to a shallow peat lake. Ecol Eng 83:78-89

Jaeger D (1994) Effects of hypolimnetic water aeration and ironphosphate precipitation on the trophic level of Lake Krupunder. Hydrobiologia 275(276):433-444

Jensen HS, Kristensen P, Jeppesen E, Skytthe A (1992) Iron:phosphorus ratio in surface sediment as an indicator of phosphate release from aerobic sediments in shallow lakes. Hydrobiologia 235(236):731-743

Jeppesen E, Kristensen P, Jensen JP, Søndergaard M, Mortensen E, Lauridsen T (1991) Recovery resilience following a reduction in external phosphorus loading of shallow, eutrophic Danish lakes: duration, regulating factors and methods for overcoming resilience. Mem Ist Ital Idrobiol 48:127-148

Jeppesen E, Søndergaard M, Lauridsen TL, Davidson TA, Liu $\mathrm{Z}$, Mazzeo N et al (2012) Biomanipulation as a restoration tool to combat eutrophication: recent advances and future challenges. In: Woodward G, Jacob U, O'Gorman EJ (eds) Advances in ecological research, vol 47. Elsevier, London, pp 411-488

Jones HE, Etherington JR (1970) Comparative studies of plant growth and distribution in relation to waterlogging: I. The survival of Erica cinerea L. and E. tetralix L. and its apparent relationship to iron and manganese uptake in waterlogged soil. J Ecol 58:487-496

Kamal M (2004) Phytoaccumulation of heavy metals by aquatic plants. Environ Int 29:1029-1039

Keller AA, Garner K, Miller RJ, Lenihan HS (2012) Toxicity of nano-zero valent iron to freshwater and marine organisms. PLoS ONE 7:e43983

Khan S, Nugegoda D (2007) Sensitivity of juvenile freshwater crayfish Cherax destructor (Decapoda: Parastacidae) to trace metals. Ecotox Environ Safe 68:463-469

Khangarot BS (1991) Toxicity of metals to a freshwater tubificid worm, Tubifex tubifex (Muller). B Environ Contam Tox 46:906-912

Khangarot BS, Ray PK (1989) Sensitivity of midge larvae of Chironomus tentans Fabricius (Diptera Chironomidae) to heavy metals. B Environ Contam Tox 42:325-330

Klapwijk SP, Kroon JMW, Meijer M-L (1982) Available phosphorus in lake sediments in The Netherlands. Hydrobiologia 92:491-500 
Kleeberg A, Schubert H, Koschorreck M, Nixdorf B (2006) Abundance and primary production of filamentous green algae Zygogonium ericetorum in an extremely acid $(\mathrm{pH}$ 2.9) mining lake and its impact on alkalinity generation. Freshw Biol 51:925-937

Kleeberg A, Köhler A, Hupfer M (2012) How effectively does a single or continuous iron supply affect the phosphorus budget of aerated lakes? J Soil Sediment 12:1593-1603

Kleeberg A, Herzog C, Hupfer M (2013) Redox sensitivity of iron in phosphorus binding does not impede lake restoration. Water Res 47:1491-1502

Lamers LPM, Falla S-J, Samborska EM, Van Dulken IAR, Van Hengstum G, Roelofs JGM (2002) Factors controlling the extent of eutrophication and toxicity in sulphate-polluted freshwater wetlands. Limnol Oceanogr 47:585-593

Lamers LPM, Vile MA, Grootjans AP, Acreman MC, van Diggelen R, Evans MG, Richardson CJ, Rochefort L, Kooijman AM, Roelofs JGM, Smolders AJP (2015) Ecological restoration of rich fens in Europe and North America: from trial and error to an evidence-based approach. Biol Rev 90:182-203

Lijklema L (1977) The role of iron in the exchange of phosphate between water and sediment. In: Golterman HL (ed) Interactions between sediments and freshwater. Dr W. Junk Publishers, The Hague, pp 313-317

Linton TK, Pacheco MAW, McIntyre DO, Clement WH, Goodrich-Mahoney J (2007) Development of bioassessment-based benchmarks for iron. Environ Tox Chem 26:1291-1298

Lucaç M, Aegerter R (1993) Influence of trace metals on growth and toxin production of Microcystis aeruginosa. Toxicon 31:293-305

Lucassen ECHET, Smolders AJP, Roelofs JGM (2000) Increased groundwater levels cause iron toxicity in Glyceria fluitans (L.). Aquat Bot 66:321-327

Martin TR, Holdich DM (1986) The acute lethal toxicity of heavy metals to peracarid crustaceans (with particular reference to freshwater asellids and gammarids). Water Res 20:1137-1147

Martin JH, Gordon M, Fitzwater SE (1991) The case for iron. Limnol Oceanogr 36:1793-1802

Molot LA, Li G, Findlay DL, Watson SB (2010) Iron-mediated suppression of bloom-forming cyanobacteria by oxine in a eutrophic lake. Freshw Biol 55:1102-1117

Mortimer CH (1941) The exchange of dissolved substances between mud and water in lakes. J Ecol 29:280-329

Mukhopadhyay MK, Konar SK (1984) Toxicity of copper, zinc, and iron to fish, plankton and worm. Geobios 11:204-207

Myllynen K, Ojutkangas E, Nikinmaa M (1997) River water with high iron concentration and low $\mathrm{pH}$ causes mortality of Lamprey Roe and newly hatched larvae. Ecotox Environ Safe 36:43-48

Nayek S, Gupta S, Saha R (2010) Effects of metal stress on biochemical response of some aquatic macrophytes growing along an industrial waste discharge channel. J Plant Int 5:91-99

Nishiuchi Y, Yoshida K (1972) Toxicities of pesticides to some fresh water snails. Bull Agric Chem Insp Stn 12:86-92

Pan DY, Liang XM (1993) Safety study of pesticides on bog frog, a predatory natural enemy of pest in paddy field. J Hum Agric Coll 19:47-54
Quaak M, Van der Does J, Boers P, Van der Vlugt J (1993) A new technique to reduce internal phosphorus loading by inlake phosphate fixation in shallow lakes. Hydrobiologia 253:337-344

Randall S, Harper D, Brierley B (1999) Ecological and ecophysiological impacts of ferric dosing in reservoirs. Hydrobiologia 395(396):355-364

Rasmussen K, Lindegaard C (1988) Effects of iron compounds on macroinvertebrate communities in a Danish lowland river system. Water Res 22:1101-1108

Sealey WM, Lim C, Klesius PH (1997) Influence of the dietary level of iron from iron methionine and iron sulfate on immune response and resistance of channel catfish to $E d$ wardsiella ictaluri. J World Aquacult Soc 28:142-149

Shuhaimi-Othman M, Nadzifah Y, Nur-Amalina R, Umirah NS (2012a) Deriving freshwater quality criteria for iron, lead, nickel, and zinc for protection of aquatic life in Malaysia. Sci World J 2012:1-7

Shuhaimi-Othman M, Nur-Amalina R, Nadzifah Y (2012b) Toxicity of metals to a freshwater snail, Melanoides tuberculata. Sci World J 2012:1-10

Sinha S, Basant A, Malik A, Singh KP (2009) Iron-induced oxidative stress in a macrophyte: a chemometric approach. Ecotox Environ Safe 72:585-595

Siqueira-Silva AI, Da Silva LC, Azevedo AA, Oliva MA (2012) Iron plaque formation and morphoanatomy of roots from species of restinga subjected to excess iron. Ecotox Environ Safe 78:265-275

Smith VH, Schindler DW (2009) Eutrophication science: where do we go from here? Trends Ecol Evol 24:201-207

Smolders AJP, Roelofs JGM, Den Hartog C (1996) Possible causes for the decline of the water soldier (Stratiotes aloides L.) in the Netherlands. Arch Hydrobiol 136:327-342

Smolders AJP, Lamers LPM, Moonen M, Zwaga K, Roelofs JGM (2001) Controlling phosphate release from phosphate-enriched sediments by adding various iron compounds. Biogeochemistry 54:219-228

Smolders AJP, Lamers LPM, Lucassen ECHET, Van der Velde G, Roelofs JGM (2006) Internal eutrophication: how it works and what to do about it - a review. Chem Ecol 22:93-111

Snowden RED, Wheeler BD (1993) Iron toxicity to fen plant species. J Ecol 81:35-46

Snowden RED, Wheeler BD (1995) Chemical changes in selected wetland plant species with increasing Fe supply, with specific reference to root precipitates and Fe tolerance. New Phytol 131:503-520

Søndergaard M, Jensen JP, Jeppesen E (2003) Role of sediment and internal loading of phosphorus in shallow lakes. Hydrobiologia 506(509):135-145

Spijkerman E, Barua D, Gerloff-Elias A, Kern J, Gaedke U, Heckathorn SA (2007) Stress responses and metal tolerance of Chlamydomonas acidophila in metal-enriched lake water and artificial medium. Extremophiles 11:551-562

Utkilen H, Gjolme N (1995) Iron-stimulated toxin production in Microcystis aeruginosa. Appl Environ Microbiol 61:797-800

Van Anholt RD, Spanings FAT, Knol AH, Van der Velden JA, Wendelaar Bonga SE (2002) Effects of iron sulfate dosage on the water flea (Daphnia magna Straus) and early 
development of carp (Cyprinus carpio L.). Arch Environ Con Tox 42:182-192

Van der Wal JEM, Dorenbosch M, Immers AK, Vidal Forteza C, Geurts JJM, Peeters ETHM et al (2013) Invasive crayfish threaten the development of submerged macrophytes in lake restoration. PLoS ONE 8:e78579

Van der Welle MEW, Cuppens M, Lamers LPM, Roelofs JGM (2006) Detoxifying toxicants: interactions between sulfide and iron toxicity in freshwater wetlands. Environ Tox Chem 25:1592-1597

Van der Welle MEW, Niggebrugge K, Lamers LPM, Roelofs JGM (2007a) Differential responses of the freshwater wetland species Juncus effusus L. and Caltha palustris L. to iron supply in sulfidic environments. Environ Pollut 147:222-230

Van der Welle MEW, Smolders AJP, Op den Camp HJM, Roelofs JGM, Lamers LPM (2007b) Biogeochemical interactions between iron and sulphate in freshwater wetlands and their implications for interspecific competition between aquatic macrophytes. Freshw Biol 52:434-447

Van Donk E, Grimm MP, Heuts PGM, Blom G, Everards K, Van Tongeren OFR (1994) Use of mesocosms in a shallow eutrophic lake to study the effects of different restoration measures. Arch Hydrobiol 40:283-294

Van Liere L, Janse JH (1992) Restoration and resilience to recovery of the Lake Loosdrecht ecosystem in relation to its phosphorus flow. Hydrobiologia 233:95-104
Verberk WCEP, Munckhof PJJ, Pollux BJA (2012) Niche segregation in two closely related species of stickleback along a physiological axis: explaining multidecadal changes in fish distribution from iron-induced respiratory impairment. Aquat Ecol 46:241-248

Vuori K-M (1995) Direct and indirect effects of iron on river ecosystems. Ann Zool Fenn 32:317-329

Walker WWJ, Westerberg CE, Schuler DJ, Bode JA (1989) Design and evaluation of eutrophication control measures for the St. Paul water supply. Lake Reserv Manage 5:71-83

Walker CH, Sibly RM, Hopkin SP, Peakall DB (2012) Principles of ecotoxicology, 4th edn. Taylor \& Francis Group, London

Wheeler BD, Al-Farraj MM, Cook RED (1985) Iron toxicity to plants in base-rich wetlands: comparative effects on the distribution and growth of Epilobium hirsutum L. and Juncus subnodulosus Schrank. New Phytol 100:653-669

Wollmann K (2000) Corixidae (Hemiptera, Heteroptera) in acidic mining lakes with $\mathrm{pH} \leq 3$ in Lusatia, Germany. Hydrobiologia 433:181-183

Wollmann K, Deneke R, Nixdorf B, Packroff G (2000) Dynamics of planktonic food webs in three mining lakes across a pH gradient ( $\mathrm{pH} 2-4)$. Hydrobiologia 433:3-14

Zak D, Gelbrecht J, Steinberg CEW (2004) Phosphorus retention at the redox interface of peatlands adjacent to surface waters in northeast Germany. Biogeochem 70:357-368 